\title{
A post mortem study of fracture of Long Bones
}

\author{
Rahul G. Peddawad ${ }^{1, *}$, Ruta Bapat ${ }^{2}$ \\ ${ }^{\mathbf{1}}$ Assistant Professor, Dept. of Forensic Medicine, ${ }^{\mathbf{2}}$ Assistant Professor, Dept. of Anatomy, Dr. DY Patil Medical College, Nerul, \\ Navi Mumbai
}

*Corresponding Author:

Email: rahul.peddawad@dypatil.edu

\begin{abstract}
Mechanical trauma of adequate force, whatever the nature of the agent, usually leads to a wound. The latter may be limited to the tissues covering the outer and inner surface of the body, namely skin and mucous membranes, giving rise to a superficial injury, or may involve as well one or more of the deeper structures like bone leading to fracture. Examination of an injury in both living and dead is an important medico-legal issue in the field of crime investigation to fix the liability. A doctor is required to date injuries specifically and individually while preparing an injury report. In all traumatic deaths where fractures were found over the body, it is important to find out whether these injuries were caused while alive and not after death of a person. The forensic pathologist can be confronted with the estimation of fracture age in association with murder, manslaughter, and bodily harm with fatal consequences, (primarily survived) accidents and further constellations. In this paper we have studied the sequential Gross and Histopathological Changes at the Site of Fracture injuries and compared the findings with available standard data. Total 78 Medicolegal deaths having long bone fractures over the body, brought for post-mortem examination, over a period of two year were studied.
\end{abstract}

Keywords: Injury, Fracture, Medico-legal

\section{Introduction}

Mechanical trauma of adequate force, whatever the nature of the agent, usually leads to a wound. The latter may be limited to the tissues covering the outer and inner surface of the body, namely skin and mucous membranes, giving rise to a superficial injury, or may involve as well one or more of the deeper structures like bone leading to fracture. Fracture is a complete or incomplete break in the continuity of a bone. Although in most fractures, there is a distinct history of trauma. ${ }^{(1,2)}$ Diagnosis of a Fracture ${ }^{1}$ can nearly always be inferred from the history and clinical examination. However, clinical evidence must always be confirmed or refuted by radiological examination. Some fairly constant signs of fracture which should arouse suspicion include: (i) local swelling, (ii) local tenderness, (iii) visible or palpable deformity and (iv) impairment of function. Dating of an injury in both living and dead is an important medicolegal issue in the field of crime investigation to fix the liability. A doctor is required to date injuries specifically and individually while preparing an injury report.

In all traumatic deaths where fractures were found over the body, it is important to find out whether these injuries were caused while alive and not after death of a person. Fracture age describes the time interval between the infliction of a fracture of bone and the time of death, and in living person till time of examination. ${ }^{(1)}$ It can be considered as the survival time of the individual following a physical injury. The forensic pathologist can be confronted with the estimation of fracture age in association with murder, manslaughter, and bodily harm with fatal consequences, (primarily survived) accidents and further constellations.
A forensic expert must be able to distinguish vital reactions from agonal as well as supravital reactions and finally from post-mortem changes. While agonal changes can arise during a state of vita minima, changes are considered to represent a supravital reaction if they are expressed after circulatory arrest and may have the appearance of a vital reaction. ${ }^{(1)}$ Dating of an injury both in the living and dead is an important medico legal problem in the field of investigation of crime. Moreover, all the injuries found on the body of a victim might not have been inflicted at the same time and even on the same day. Though it will not be possible to give exact time of infliction of injury, yet approximate age of the injury can be made out from the reparative changes that occur after infliction of any injury; reaction to injury is immediate, and it continues until the repair is complete. (2)

The bone healing process is greatly influenced by a variety of systemic and local factors. A thorough understanding of the basic science of bone healing as well as the many factors that can affect it is highly critical to time it.

\section{Objectives of the Study}

1. To study Gross and Histo-pathological changes at the site of Fracture.

2. To study the time since infliction of Fracture Injuries.

3. To compare gross changes with histo-pathological changes at site of fracture in relation to time.

\section{Material and Method}

The study was carried out with an objective to study certain medico legal aspects of Fractures on the basis of 
its gross \& histopathological examination at the time of post-mortem.

Study Setting: The Study conducted at tertiary care hospital in Mumbai

Study Design: Cross Sectional Study. Descriptive study Sample Size: During the study, a total no. of 78 Fracture injury cases were studied. The cases having mechanical injuries in the form fractures brought to PM centre attached to the tertiary hospitals for post-mortem examination. All ante mortem and post-mortem fractures of long bones in the body of deceased have been studied. Inclusion Criteria: All 78 cases of fracture studied were having fracture of long bone in diaphysis i.e. at mid shaft $\&$ the exact time of infliction of injuries is known.

Exclusion Criteria: Bodies which are decomposed \& Fractures over the deceased having history of vascular insufficiency, malnutrition, bone diseases, location other than long bone diaphysis \& the cases where the exact time of infliction of injuries is not known.

Methodology: In all the cases detailed history was collected from relatives, police officer, and from the notes on indoor hospital papers by treating doctors in cases of hospital deaths. The study was conducted at department of Forensic Medicine in collaboration with department of pathology, at tertiary care hospital in Mumbai. The Study included gross \& histopathological examination of long bone fractures. The formalin-fixed, paraffin-embedded samples of fracture ends and surrounding tissue were stained in hematoxylin and eosin \& studied under microscope.

\section{Observations and Results}

Table 1: Age distribution among study group

\begin{tabular}{|l|c|c|c|c|c|}
\hline & $\begin{array}{c}\text { No. of } \\
\text { Cases }\end{array}$ & $\begin{array}{c}\text { Minimum } \\
\text { Age }\end{array}$ & $\begin{array}{c}\text { Maximu } \\
\mathbf{m} \\
\text { Age }\end{array}$ & $\begin{array}{c}\text { Mean } \\
\text { Age }\end{array}$ & $\begin{array}{c}\text { Std. } \\
\text { Deviation }\end{array}$ \\
\hline Age(years) & 78 & 15 & 58 & 34.62 & 6.45 \\
\hline
\end{tabular}

Table 1: Table showing age distribution among study group of deceased having fractures. Total 78 fracture cases were studied with minimum age of deceased person 15 yrs and maximum age was 58 yrs with mean of $34.62 \pm 6.45$.

Table 2: Gender wise distribution of fracture injuries

\begin{tabular}{|l|c|c|}
\hline & No. of Cases & Percent \\
\hline Females & 18 & 23.08 \\
\hline Males & 60 & 76.92 \\
\hline Total & 78 & 100.0 \\
\hline
\end{tabular}

Table 2: Table showing gender wise distribution of fractures among deceased persons. Among 78 cases of fracture, $18(23.08 \%)$ were females and $60(76.92 \%)$ were males.
Table 3: Distribution of fractures according to location

\begin{tabular}{|l|c|c|}
\hline \multicolumn{3}{|c|}{ Location of Fracture } \\
\hline \multicolumn{1}{|c|}{ Location } & No. of Cases & Percent \\
\hline Mid Shaft & 78 & 100.0 \\
\hline Peri Articular & 0 & 0 \\
\hline Total & 78 & 100.0 \\
\hline
\end{tabular}

Table 3: Table showing distribution of fracture cases according to their location. All 78 cases of fracture studied were having fracture of long bone in diphysis i.e. at midshaft.

Table 4: Distribution of fractures according to pattern

\begin{tabular}{|l|c|c|}
\hline \multicolumn{3}{|c|}{ Pattern of Fracture } \\
\hline \multicolumn{1}{|c|}{ Pattern } & No of Cases & Percent \\
\hline Comminuted & 12 & 15.38 \\
\hline Transverse & 48 & 61.54 \\
\hline Oblique & 18 & 23.08 \\
\hline Total & 78 & 100.0 \\
\hline
\end{tabular}

Table 4: Table showing distribution of fractures according to their pattern. 18 fractures $(23.08 \%)$ were oblique, 48 fractures $(61.54 \%)$ were transverse (single plane) type and $12(15.38 \%)$ was comminuted type.

Table 5: Distribution of fractures according to type of fracture

\begin{tabular}{|l|c|c|}
\hline \multicolumn{3}{|c|}{ Type of Fracture } \\
\hline \multicolumn{1}{|c|}{ Type } & No of Cases & Percent \\
\hline Compound & 14 & 17.94 \\
\hline Simple & 64 & 82.06 \\
\hline Total & 78 & 100.0 \\
\hline
\end{tabular}

Table 5: Table showing distribution of fractures according to their type. Among 78 cases 64 (82.06\%) were simple fractures and 14 cases $(17.94 \%)$ were compound fractures.

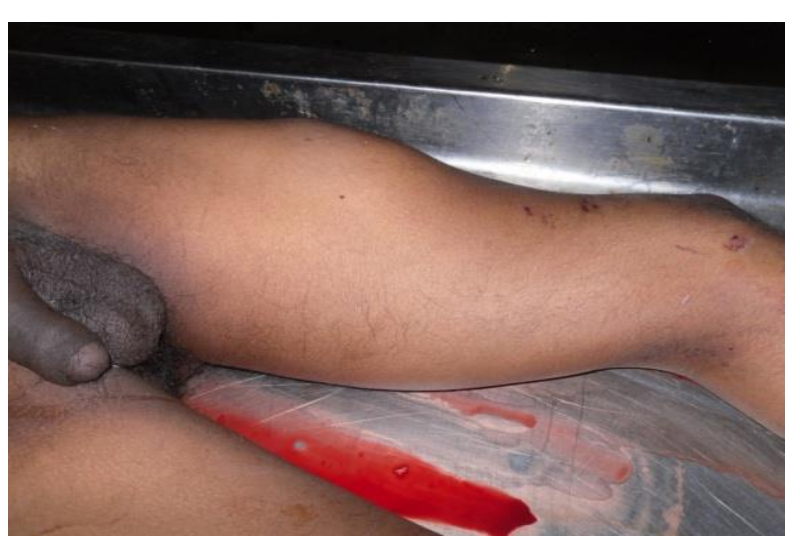

Fig. 1: Fracture of Left Femur 6 days old, swelling can be seen 


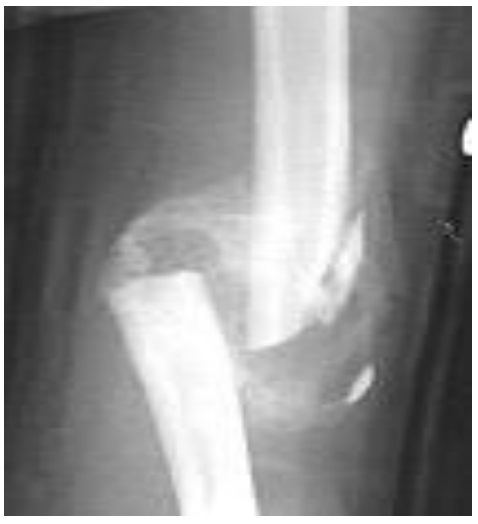

Fig. 2: Hematoma formation around the fracture can be seen on X-ray 6 days old

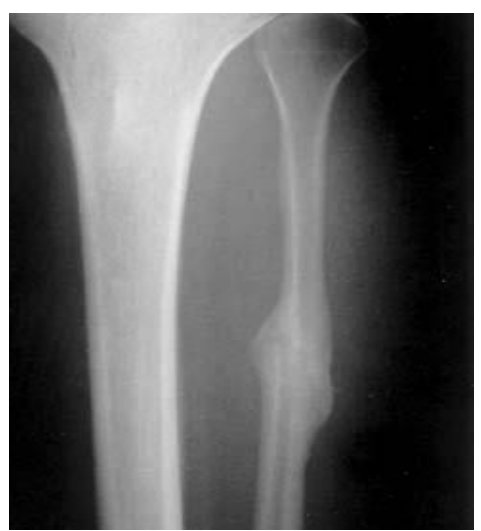

Fig. 3: Soft tissue callus formation seen on $X$-ray 30 days old fracture injury

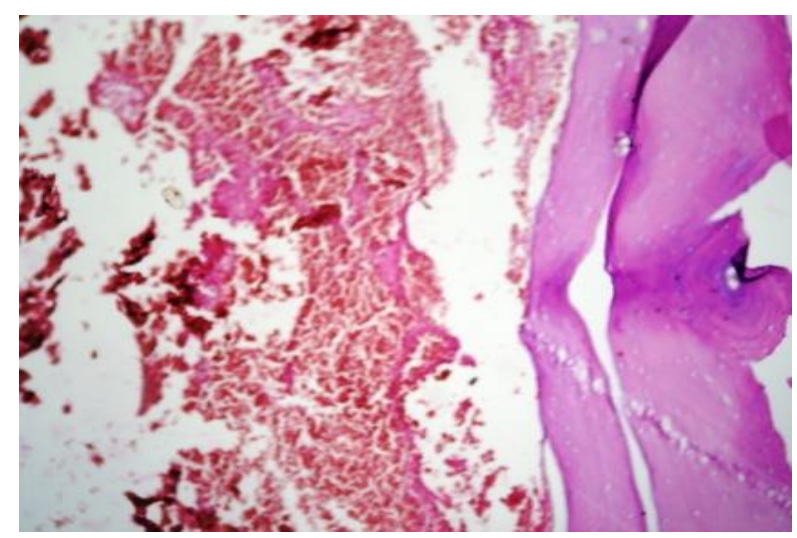

Fig. 4: Inset showing Histopathology of $24 \mathrm{hrs}$ old fracture, showing cortical bone along with hematoma.(H \& E, - X100).(H \& E, - X100)

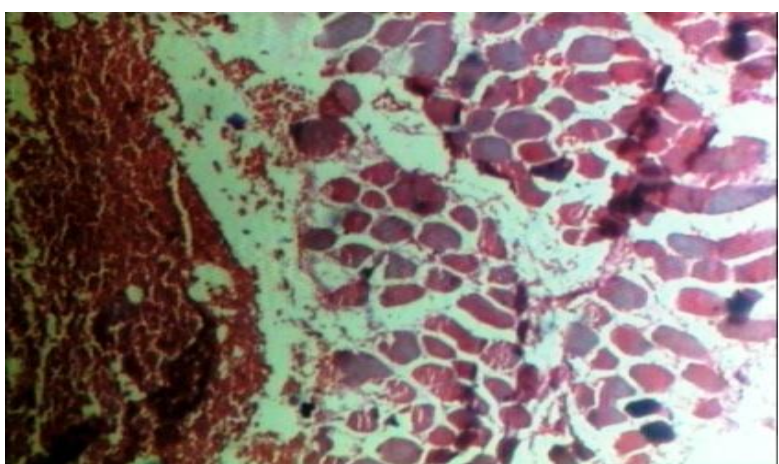

Fig. 5: Inset showing RBC's infiltration due to hemorrhage within striated muscle 72 hour old fracture. $(\mathrm{H} \& \mathrm{E},-\mathrm{X} 100)$

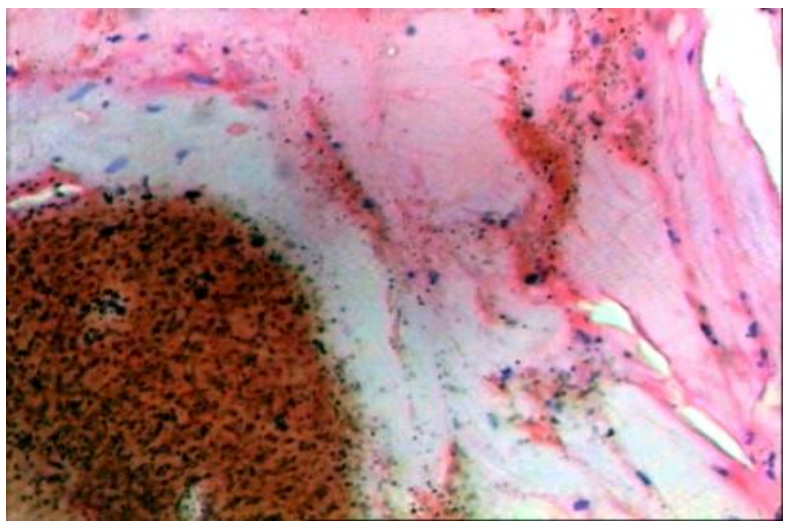

Fig. 6: Histopathology of fracture ends of bone showing well organized hematoma adjacent to bone 6 days old.(H \& E, - X100)

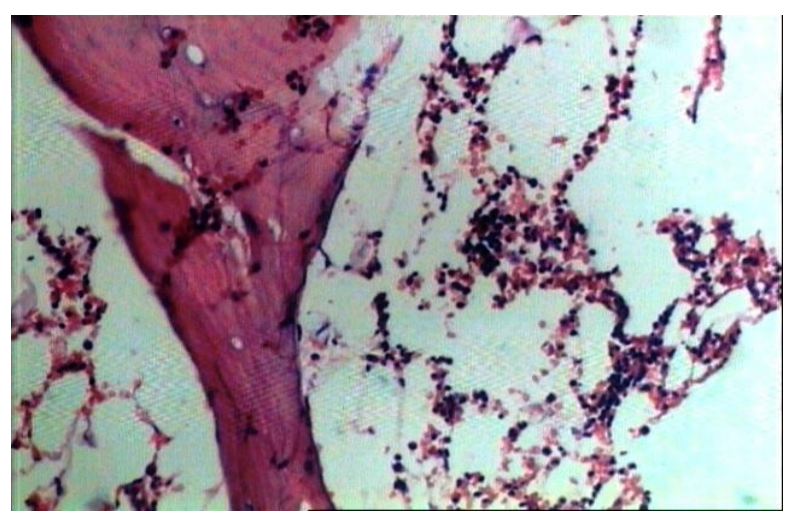

Fig. 7: Histopathology showing bone along with hemorrhage and infiltration of chronic inflammatory cells $\&$ phagocytic cells in surrounding adipose tissue in 4 days old compound fracture.(H\&E, X200) 


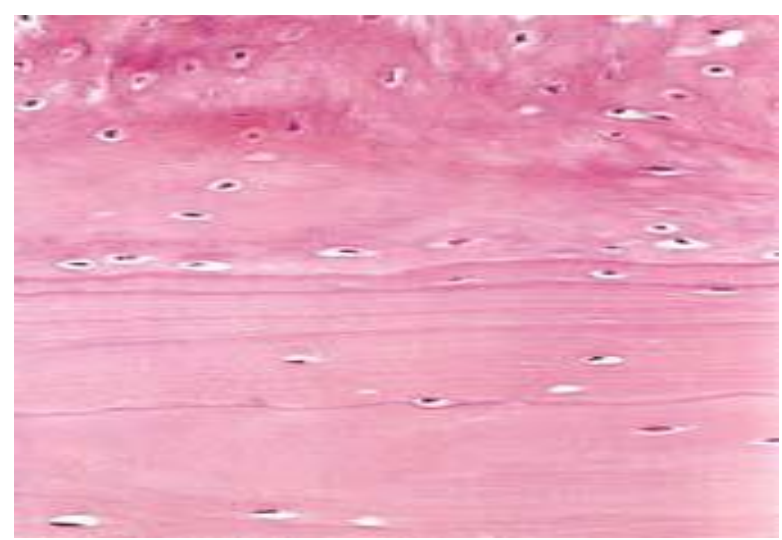

Fig. 8: Woven bone (top) deposited on the surface of pre-existing lamellar bone (bottom) in $>60$ days old fracture $(H \& E, X 400)$

Table 6: Gross \& histopathological examination findings (parameter*) noted at the time of post mortem ${ }^{(3,4,}$ $5,6,7,8,9,10,11)$

\begin{tabular}{|c|c|c|}
\hline $\begin{array}{l}\text { Stages } \\
\text { Fracture } \\
\text { Healing }\end{array}$ & $\begin{array}{l}\text { Gross examination findings at the time of } \\
\text { post mortem (parameter*) found in these } \\
\text { injuries }\end{array}$ & $\begin{array}{l}\text { HISTOPATHOLOGICAL examination } \\
\text { findings (parameter*)found in these injuries }\end{array}$ \\
\hline $\begin{array}{l}\text { Stage } \\
\text { hematoma }\end{array}$ & $\begin{array}{l}\text { 1. E/o extravasations of blood } \\
\text { 2. E/o swelling of tissue around the fracture } \\
\text { 3. E/o bruising of skin and tissue in and } \\
\text { around the fracture/ staining of the edges } \\
\text { of fracture } \\
\text { 4. E/o blood clots/ hematoma formation } \\
\text { around the fracture } \\
\text { a. soft in consistency } \\
\text { b. firm in consistency }\end{array}$ & $\begin{array}{l}\text { A. E/o RBC's infiltration into surrounding } \\
\text { tissue. } \\
\text { B. E/o Hematoma formation and fibrin } \\
\text { deposition }\end{array}$ \\
\hline $\begin{array}{l}\text { Stage of } \\
\text { Inflammation } \\
\& \text { granulation } \\
\text { tissue } \\
\text { formation }\end{array}$ & $\begin{array}{l}\text { 5. E/o local inflammatory response with } \\
\text { exudation } \\
\text { 6. E/o evidence of infection (Pus) } \\
\text { 7. E/o evidence of ingrowths of granulation } \\
\text { tissue }\end{array}$ & $\begin{array}{l}\text { C. E/o necrosis of ends of bone } \\
\text { D. E/o inflammatory cells and phagocytic cells } \\
\text { E. E/o formation of capillaries, fibroblasts, } \\
\text { osteoblasts, soft granulation tissue } \\
\text { F. E/o granulation tissues }\end{array}$ \\
\hline $\begin{array}{l}\text { Stage of callus } \\
\text { formation }\end{array}$ & $\begin{array}{l}\text { 8. E/o soft tissue callus formation } \\
\text { 9. E/o woven bone callus formation }\end{array}$ & $\begin{array}{l}\text { G. E/o soft tissue callus (i.e. procallus) } \\
\text { H. E/o osteoblastic activity seen at periosteal } \\
\text { and medullary region. } \\
\text { I. E/o conversion of procallus to } \\
\text { fibrocartilagenous callus and woven bones. } \\
\text { J. E/o chondroblast, chondrocytes or } \\
\text { developing cartilage in the callus }\end{array}$ \\
\hline $\begin{array}{ll}\text { Stage } & \text { of } \\
\text { remodeling } & \& \\
\text { modeling } & \end{array}$ & $\begin{array}{l}\text { 10. E/o osseous callus formation (lamellar } \\
\text { bone) }\end{array}$ & $\begin{array}{l}\text { K. E/o replacement of fibrocartilagenous callus } \\
\text { by osseous bone (lamellar bone) }\end{array}$ \\
\hline
\end{tabular}

Table 7: Comparison of age of fracture from history with gross examination and H.P. examination findings

\begin{tabular}{|c|c|c|c|c|c|c|}
\hline \multirow[t]{2}{*}{$\begin{array}{l}\text { S. } \\
\text { No }\end{array}$} & \multicolumn{2}{|c|}{ Age of injury as per history } & \multicolumn{2}{|c|}{$\begin{array}{c}\text { Gross examination parameter* } \\
\text { found in these injuries }\end{array}$} & \multicolumn{2}{|c|}{$\begin{array}{l}\text { HP examination parameter* } \\
\text { found in these injuries }\end{array}$} \\
\hline & $\begin{array}{c}\text { No. of } \\
\text { Fracture }\end{array}$ & Age & No. of cases & parameter* & No. Of cases & parameter* \\
\hline \multirow[t]{2}{*}{1} & \multirow{2}{*}{$\begin{array}{l}26 \\
(33.33 \%) \\
\end{array}$} & \multirow[t]{2}{*}{ Less than 24 Hours } & $19(24.36 \%)$ & $1,2,3,4 a, 5$ & $19(24.36 \%)$ & A,D \\
\hline & & & $7(8.97 \%)$ & $1,3,4 a, 5$ & $7(8.97 \%)$ & $\mathrm{A}, \mathrm{C}, \mathrm{D}$ \\
\hline \multirow[t]{2}{*}{2} & \multirow{2}{*}{$\begin{array}{l}22 \\
(28.20 \%)\end{array}$} & \multirow[t]{2}{*}{24 to 72 Hours } & $17(21.79 \%)$ & $1,2,3,4 \mathrm{a} / 4 \mathrm{~b}, 5$ & $17(21.79 \%)$ & $\mathrm{A}, \mathrm{B}, \mathrm{C}, \mathrm{D}$ \\
\hline & & & $5(6.41 \%)$ & $3,5,6$ & $5(6.41 \%)$ & A,C,D \\
\hline \multirow[t]{2}{*}{3} & \multirow{2}{*}{$\begin{array}{l}9 \\
(11.53 \%)\end{array}$} & \multirow[t]{2}{*}{4 day to 7 day } & $8(10.25 \%)$ & $2,3,4 b, 7$ & $8(10.25 \%)$ & $\mathrm{A}, \mathrm{B}, \mathrm{C}, \mathrm{D}, \mathrm{E}$ \\
\hline & & & $1(1.28 \%)$ & 5,6 & $1(1.28 \%)$ & $\mathrm{C}, \mathrm{D}$ \\
\hline
\end{tabular}




\begin{tabular}{|l|l|l|c|c|c|c|}
\hline 4 & 5 & 8 day to 14 day & $4(5.13 \%)$ & 5,7 & $4(5.13 \%)$ & D,E,F \\
\cline { 4 - 7 } & $(6.41 \%)$ & & $1(1.28 \%)$ & 6,7 & $1(1.28 \%)$ & D, E \\
\hline 5 & $4(5.13 \%)$ & 15 day to 30 day & $4(5.13 \%)$ & 7,8 & $4(5.13 \%)$ & E,F,G \\
\hline 6 & $3(3.85 \%)$ & 31 day to 45 day & $3(3.85 \%)$ & 7,8 & $3(3.85 \%)$ & F,G,H \\
\hline 7 & $2(2.56 \%)$ & $>45$ days & $2(2.56 \%)$ & 8,9 & $2(2.56 \%)$ & G,I \\
\hline 8 & $7(8.97 \%)$ & ADI & $3(3.85 \%)$ & 1 & $3(3.85 \%)$ & ----- \\
\cline { 3 - 6 } & & $4(5.13 \%)$ & ----- & $4(5.13 \%)$ & ----- \\
\hline
\end{tabular}

(* - refer Table no.1, ADI - Injuries inflected after Death)

Tables 6 and 7 shows result of Gross \& Histopathological examination findings which were used as a parameter to time the fracture. These Gross \& Histopathological findings are compared with time of their infliction as per history.

\section{Discussion}

The Healing of fractures is in many ways similar to the healing of soft-tissue wounds, except that the end result is mineralized mesenchymal tissue, i.e. bone. ${ }^{(3)} \mathrm{A}$ fracture begins to heal as soon as the bone is broken, and through a continuous series of stages. A continuously occurring state of bone deposition, resorption, and remodeling facilitates the healing process. The cellular components of bone consist of osteogenic precursor cells, osteoblasts, osteoclasts, osteocytes, and the hematopoietic elements of bone marrow. ${ }^{(4,5)}$ Osteoblasts are mature, metabolically active, bone-forming cells. They secrete osteoid, the unmineralized organic matrix that subsequently undergoes mineralization, giving the bone its strength and rigidity. Osteoblasts also play a role in the activation of bone resorption by osteoclasts.

There are three primary types of bone: woven bone, cortical bone, and cancellous bone. ${ }^{(3,4)}$ Woven bone is found during embryonic development, during fracture healing (callus formation). Woven bone is normally remodelled and replaced with cortical or cancellous bone. Osteoid is the unmineralized organic matrix secreted by osteoblasts. It is composed of $90 \%$ type I collagen and $10 \%$ ground substance, which consists of non-collagenous proteins, glycoproteins, proteoglycans, peptides, carbohydrates, and lipids. The mineralization of osteoid by inorganic mineral salt calcium phosphate provides bone with its strength and rigidity. ${ }^{(5,6)}$

Healing occurs in overlapping stages of: 1) Stage of hematoma; 2) Stage of Inflammation \& granulation tissue formation; 3) Stage of callus; 4) Stage of remodelling \& modelling (Consolidation). ${ }^{(7,8,9)}$ Stage of haematoma: This stage lasts for 7- 10 days. When a bone is fractured, blood leaks out through torn vessels in the bone and forms a haematoma between and around the fracture. ${ }^{(10,11)}$ Stage of Inflammation \& granulation tissue formation : This stage lasts for about 2-4 weeks. In this stage, Inflammatory cells (macrophages, monocytes, lymphocytes, and polymorphonuclear cells) and fibroblasts infiltrate the bone under prostaglandin mediation. The sensitised precursor cells (daughter cells) produce cells which differentiate and organise to provide blood vessels, fibroblasts, osteoblasts etc. Collectively they form a soft granulation tissue in the space between the fracture fragments. Stage of callus (Woven bone) Formation: This stage lasts for about 4-12 weeks. In this stage, the granulation tissue differentiates further and creates osteoblasts. These cells lay down an intercellular matrix which soon becomes impregnated with calcium salts. This results in formulation of the callus, also called woven bone. The callus is the first sign of union visible on X-rays, usually 3 weeks after the fracture. Stage of remodeling \& modelling (Consolidation): in this stage, the woven bone is replaced by mature bone with a typical lamellar structure. Adequate strength is typically achieved in 3 to 6 months. ${ }^{(8,12)}$

In present study, death has occurred within 24 hours of infliction of fracture in $26(33.33 \%)$ cases. Out of these $26(33.33 \%)$ cases $19(24.36 \%)$ were of simple fracture \& $7(8.97 \%)$ were of compound fracture. On Gross examination, 19 (24.36\%) cases of simple fracture have shown [P1] - extravasation of blood, [P2] swelling of tissue around the fracture, [P3] - bruising of skin and tissue around the fracture \& staining of the edges of fracture, [P 4a] - Blood clots or soft hematoma $\&$ [P 5]- signs of inflammation and remaining 7 (8.97\%) fractures were compound and have shown all above finding but there was no visible swelling \& no hematoma formation around fracture ends. On Histopathological examination, all $26(33.33 \%)$ cases have shown [P-A] $\mathrm{RBC}$ infiltration in the surrounding tissue and in fracture ends \& [P-D]- Inflammatory cells. Inflammatory reaction with necrosis of fracture ends $[\mathrm{P}-\mathrm{C}]$ is more evident in open wounds i.e. in compound fracture than the cases of simple fracture.

$22(28.20 \%)$ cases where death has occurred after 24 hours but within 72 hours of infliction of fracture. Out of these 22 cases, 17 were of simple fracture \& 5 were of compound fracture. On Gross examination findings are almost similar as in above 18 cases except hematoma is much more organized and firm in consistency in simple i.e. closed fractures while pus formation is more evident in compound fracture. On Histopathological examination of these fracture inflammatory cells \& phagocytic cells are more evident.

$9(11.53 \%)$ cases where death has occurred between 4 to 7 days of infliction of fracture. Out of these 9 cases, $8(10.25 \%)$ were of simple fracture \& $1(1.28 \%)$ were of compound fracture. On Gross \& Histopathological examination, all 9 cases have shown diffuse bruising of tissue around the fracture, organized hematoma \& granulation tissue. 
$5(6.41 \%)$ cases where death has occurred between 8 to 14 days of infliction of fracture. Out of these 5 cases 4 were of simple fracture \& 1 was of compound fracture. On Gross examination, 4 cases of simple fracture have shown in growth of granulation tissue, while 1 compound fracture of age 14 days have shown inflammatory signs with exudation along with granulation tissue \& purulent discharge at places. On Histopathological examination of simple fractures have shown osteoblastic activity with granulation tissue.

$4(5.13 \%)$ cases of simple fracture where death has occurred between 15 to 30 days of infliction of fracture. On Gross examination all these fractures have shown in growth of granulation tissue \& Soft Callus bridging the gap of fracture ends. On Histopathological examination granulation tissue \& Soft tissue callus was evident.

$3(3.85 \%)$ cases of simple fracture where death has occurred between 31 to 45 days of infliction of fracture. On Gross examination all these fractures have shown in growth of Soft Callus bridging the gap of fracture ends. On Histopathological examination granulation tissue \& Soft tissue callus was evident.

$2(2.56 \%)$ cases of simple fracture where death has occurred later than days of infliction of fracture. Gross \& Histopathological examination have shown woven bone callus formation.

$7(14 \%)$ cases have not shown any change at fracture ends on gross \& Histopathological examination, where fracture were inflicted after death.

There is no similar study is available to compare our findings except literature on bone healing that mentioned in standard textbooks. It is not possible to determine exactly the age of an injury on the basis of its appearance to the naked eye. The results obtained are erroneous because of variability of the intensity of local inflammatory reaction. ${ }^{(1,3,7,12)}$

\section{Limitation of Study}

Factors affecting healing process are not studied in this study as all cases selected for this study are healthy individuals; this is one of the limitations of this study. Study of enzyme histochemistry of wound as documented in literature which is also one of the useful tool for age estimation of injury is not considered in this study which would have been additional source to arrive to more precise conclusions, is one of the limitation of the study.

\section{Summary and Conclusion}

Medico legal autopsy is an important part of an examination for scientific determination of age of Fracture. Careful gross examination study of fracture site can be helpful to arrive at conclusion about their antemortem or post-mortem nature in most of the cases. However in few cases, there are limitations to gross examination to conclude ante-mortem or post-mortem nature of fracture $\&$ to decide age of injury. Hisotpathological study to determine the age of injury is useful and advanced method which is helpful for investigation and proper administration of justice. Proper selection of tissue samples with proper preservatives and qualitative technology is necessary for perfect microscopic observation and conclusions. Histopathological examination is further helpful to give closer range of timing of infliction of fracture as compared to only gross examination. On histopathological examination of fractures of age of few hours revealed RBC's infiltration and delayed cases, callus and woven bone formation noted. Age of injury is important in disputed insurance settlement, road traffic accident claim, prisoners died in police custody and in homicidal deaths.

\section{References}

1. Tedeschi C.G., Eckert GW. \& Tedeschi LG. Forensic Medicine- a study in trauma and environmental hazards (1st ed.) W B Saunders Company. Philadelphia, London, Toronto; 1977.

2. Vij K., Injuries (Medicolegal consideration and types),"Text Book of Forensic Medicine and Toxicology", 2007, $4^{\text {th }}$ ed. Elsevier Publication, 2007. P. 259-295.

3. Maheshwari J. Essential Orthopaedics. 'Anatomy of Bone and Fracture Healing' $3^{\text {rd }}$ ed. Mehta publication, 2009. P. 6-18.

4. Copenhaver WM, Kelly DE, Wood RL: The connective tissues: cartilage and bone, in Copenhaver WM, Kelly DE, Wood RL (eds): Bailey's Textbook of Histology, $17^{\text {th }}$ ed. Baltimore: Williams \& Wilkins, 1978. P. 170-205.

5. Recker RR: Embryology, anatomy, and microstructure of bone, in Coe FL, Favus MJ (eds): Disorders of Bone and Mineral Metabolism. New York: Raven, 1992, pp 219 240.

6. Prolo DJ: Biology of bone fusion. Clin Neurosurg, 1990, 36, P. 135-146.

7. Modi JP, K Mathiharan, Amrit Patnaik. Modi's Medical Jurisprudence and Toxicology. $23^{\text {rd }}$ ed., Buttertworths publication, New Delhi; 1999. P. 685-763.

8. Knight B and Saukko P., Knight's Forensic Pathology. $3^{\text {rd }}$ ed. Arnold, Hodder Headline Group, 338 Euston Road, London NW13 BH; 2004. P.123-155.

9. Burchardt H, Enneking WF: Transplantation of bone. Surg Clin North Am 58:403-427,1978.

10. DePalma AF, Rothman RH, Lewinnek GE, et al: Anterior interbody fusion for severe cervical disc degeneration. Surg Gynecol Obstet 134. 1972. P.755-758.

11. Robert W.B., James D. 'Bone and Joint Healing' in "Rockwood and Green's Fractures in Adults" $5^{\text {th }}$ edition. Lippincott Williams ltd. P. 245- 281.

12. Samuel L.T. 'Repair of simple fracture of a long bone' in "Orthopaedics Principles and their Application" $4^{\text {th }}$ edition. Jaypee Brother pub. Ltd., P 50 -56. 